\title{
TALLINN RADIOCARBON DATES V
}

\section{J M PUNNING, R RAJAMÄE, and M EHRENPREIS}

Institute of Geology, Academy of Sciences, Estonian SSR.

The following list comprises age measurements carried out during 1976 and 1977. The activity of ${ }^{14} \mathrm{C}$ was computed by one- and two-channel scintillation devices (Punning et al, 1976; 1977). Ages are calculated using a half-life of $5568 \pm 30$ years for ${ }^{14} \mathrm{C}$ with $\mathrm{NBC}$ oxalic acid as a reference standard. All dates are reported in years before $1950 .{ }^{12} \mathrm{C} /{ }^{13} \mathrm{C}$ measurements were not performed and results are not corrected for ${ }^{13} \mathrm{C}$ fractionation.

TIn-200. Marikoja

\section{GEOLOGIC SAMPLES}

Estonian SSR

Carex/Phragmiles peat from under beach barier, NE of Kaha Lake, Harju Dist. In depression before glint near shore deposits of Iittorina Sea overlying $0.5 \mathrm{~m}$ complex organic deposits represented by Carex/ Phragmites and wood peat. In transition zone wood remains. Pollen analyses by $\mathrm{H}$ Kesel refer accumulation of lacustrine deposits to Pollen Zone AT1. Coll 1971 and subm by H Kessel, Inst Geol, Acad Sci Estonian SSR (now Inst Geol).

\section{TIn-201. Marikoja}

$7240 \pm 90$

Wood peat from same complex as Tln-200. Coll 1975 and subm by H Kessel.

\section{TIn-202. Uuri}

$9230 \pm 80$

Wood (birch) remains underlying gravel of Ancylus Lake on foot of glint at Uuri, NE of Kahala Lake, Harju Dist. Lacustrine deposits overlay gravel and till. Coll 1975 and subm by H Kessel.

\section{Tln-231. Tepanimägi}

$7660 \pm 110$

Well-decomposed peat from funnel on $\mathrm{N}$ slope of Tepanimägi hill, Otepää elev, Valga Dist. Lake and bog deposits, $2.5 \mathrm{~m}$ thick are embedded in deluvial deposits. From depth 2.45 to $2.50 \mathrm{~m}$. Coll 1973 and subm by R Karukäpp, Inst Geol.

\section{TIn-239. Ozolnieki}

\section{Latvian SSR}

Wood remains from profile near settlement O\%olnicki, Jelgava Dist. Sample from sands overlying varved clays of Baltic Glacial Iake. Coll 1976 and subm by U Veinbergs, All-Union Research Inst Marine Geol.

\section{Arkhangelsk and Murmansk Districts}

\section{TIn-192. Sija}

$31,380 \pm 350$

Shells from exposure on light bank of Severnava 1)vina $R, 300 \mathrm{~m}$ upstream from port Sija, Arkhangelsk Dist. Sample from fine sand over- 
lain by 2 tills at alt $4 \mathrm{~m}$ from river level. Coll 1975 by R Rajamäe. Comment: outer $40 \%$ removed by acid leaching.

\section{Tln-230. Sija}

$40,250 \pm 650$

Shells from exposure ca $100 \mathrm{~m}$ downstream from profile at Severnaya Dvina R where Tln-192 was taken. Sample from clayey aleurites at alt 2.6 to $3.6 \mathrm{~m}$ from river level. Coll 1975 by R Rajamäe. Comment: outer $40 \%$ removed by acid leaching.

Tln-210. Verhne-Tulomsky

$9030 \pm 90$

Shells (Hiatella arctica) from deposits of sea terrace on left bank of outflow canal of Verhne-Tulomsky Hudropower Sta, Murmansk Dist. Sample from depth 0.10 to $0.15 \mathrm{~m}$. Coll 1975 and subm by B Koshetchkin, Geol Inst, Kola Branch Acad Sci USSR. Comment: outer 40\% removed by acid leaching.

Tln-211. Paive

$6180 \pm 60$

Shells (Cyprina islandica) from profile of Middle Holocene sea terrace in valley of Paive R, Rõbatchji Peninsula, Murmansk Dist. Horizon, $0.5 \mathrm{~m}$ of fine and medium sands rich in shells lies at depth $0.6 \mathrm{~m}$. Coll 1975 and subm by B Koshetchkin, Geol Inst. Comment: outer $25 \%$ removed by acid leaching.

Tln-212. Eina

$6270 \pm 70$

Shells (Hiatella arctica) from exposure on sea terrace on right bank of Eina R, Rõbatchji Peninsula, Murmansk Dist. Clays containing shells overlain by pebble and sandy loams. Sample coll and subm by B Koshetchkin, Inst Geol. Comment: outer 40\% removed by acid leaching.

\section{Pasva series}

Exposures lie on right bank of Vaga $\mathrm{R}$ (tributory of Severnaya Dvina $\mathrm{R}$, Arkhangelsk Dist) near village Pasva, ca $4 \mathrm{~km}$ upstream from profile of Koleshki (Tln-49, -52, -71, Devyatova Punning, 1976). In profile 2 complexes of organic deposits are overlain by sandy-clayey deposits. Thermoluminescent dates on quartz showed accumulation of sediments in Pasva profile continued steadily from Mikulian up to Late Valdai period (Hütt et al, 1978). On basis of pollen evidence Devyatova correlates accumulation of organic deposits with Mikulian interglacial and Upper-Valdai interstadial (Devyatova et al, 1978). Samples coll 1975 by R Rajamäe.

\section{Tln-215. Pasva}

$34,600 \pm 1100$

Upper layer of well-decomposed wood peat, $0.7 \mathrm{~m}$ thick. Sample from depth 11.85 to $12.05 \mathrm{~m}$.

Tln-216. Pasva

Central part of same layer where Tln-215 was taken. Sample from depth 12.05 to $12.25 \mathrm{~m}$. 
TIn-217. Pasva

I.owermost part of same layer where Tln-215 was taken. Sample from depth 12.25 to $12.45 \mathrm{~m}$.

TIn-226. Pasva

$\supseteq 49,700$

Compacted wood peat from depth 12.95 to $13.05 \mathrm{~m}$.

TIn-221. Verhnaya Telza

$46,830 \pm 1100$

Shells from exposure on right bank of Verhnaya Telza R (tributory of Onega R, Arkhangelsk Dist). Gravel-pebble sand abundant in shells underlies reddish brown till and medium sands at depth 8.5 to $10.0 \mathrm{~m}$. Coll 1975 by J M Punning and R Rajamäe. Comment: outer 40\% removed by acid leaching.

TIn-222. Raibola

$40,000 \pm 800$

Well-clecomposed peat from profile on right bank of Vaga $R$ (tributory of Severnaya Dvina R, Arkhangelsk Dist). Peat in aleurites overlain by 3 tills. Previous date from same complex $\supseteq 49,000$ : Tln-77. TIn-222 apparently too young. Sample coll 1975 by R Rajamäe.

TIn-223. Lovozerskaya tundra

Wood remains from borehole in foreland depression $\mathrm{N}$ of Lovozerskaya tundra, Murmansk Dist. Lake and bog deposits, $2 \mathrm{~m}$ thick rest between cobble, gravel and sand deposits and are divided by interlayer of cobble and pebble loam into 2 complexes. Sample from depth 15.4 to $15.9 \mathrm{~m}$. Coll 1976 and subm by V Evzerov, Geol Inst.

Tln-224. Lovozerskaya tundra

$21,630 \pm 650$

Wood remains from lowermost organogenous complex of same borehole as Tln-223. Sample from depth 16.6 to $16.8 \mathrm{~m}$.

Tln-225. Lovozerskaya tundra

Wood remains from same complex as Tln-224. Sample from depth 16.8 to $17.2 \mathrm{~m}$. According to Tln-223-225, age of lake and bog deposits in profile: $\geqq 42,000 \mathrm{yr}$. Th-224 apparently too young.

\section{Tln-227. Pervomaiskji}

$39,000 \pm 800$

Peat from profile on left bank of Severnaya Dvina R, ca $10 \mathrm{~km} \mathrm{up-}$ stream from settlement of Pervomaiskji, Arkhangelsk Dist. Peat layer in aleurites buried under medium sands and gray aleurite. Sample coll 1975 by J M Punning and R Rajamäe.

TIn-229. Krasnaya Gorka

Shells from profile on right bank of Severnaya Dvina $R$ near village Krasnaya Gorka, Arkhangelsk Dist. Shells of subfossil mollusks are embedded in medium sands on aleuritic till and are covered by clayey aleurites with interlayers of fine and medium sands. Sample from depth 1.6 to $1.8 \mathrm{~m}$. Coll 1975 by R Rajamäe. Comment: outer $40 \%$ removed by acid leaching. 
Tln-240. Vajenga

Wood remains from alluvial deposits on left bank of Vajenga $R$ (tributory of Severnaya Dvina R) ca $1 \mathrm{~km}$ upstream from settlement UstVajenga. Coll 1975 and subm by E Devyatova, Geol Inst, Karelian Branch Acad Sci USSR.

Tln-248. Lodeinoye

$6040 \pm 110$

Shells (Hiatella arctica) from $22 \mathrm{~m}$ sea terrace on $\mathrm{E}$ edge of settlement Lodenoye, Murmansk Dist. Sample from depth 2.3 to $4.7 \mathrm{~m}$. Coll 1976 and subm by B Koshetchkin, Geol Inst. Comment: outer $40 \%$ removed by acid leaching.

\section{West Spitsbergen}

Tln-194. Billefjord

$34,120 \pm 600$

Shells from profile on $\mathrm{E}$ coast of Billefjord near Cape Ekholm. Pleistocene deposits represented by complex of marine deposits lying between 2 tills and fluvioglacial deposits overlying carbonaceous sandstones. Uppermost till underlies marine deposits and terrace drifts. Terrace alt $30 \mathrm{~m}$. Coll 1975 and subm by L Troitski, Inst Geog. Comment: outer 40\% removed by acid leaching.

TIn-219. Billefjord

$8760 \pm 90$

Shells from sands at depth $0.5 \mathrm{~m}$ in deposits of $30 \mathrm{~m}$ terrace on $\mathrm{E}$ coast of Billefjord near Cape Ekholm (see Tln-194). Coll 1975 and subm by L Troitski. Comment: outer $40 \%$ removed by acid leaching.

Tln-199. Billefjord

$7370 \pm 80$

Shells from surface of $20 \mathrm{~m}$ terrace on $\mathrm{E}$ coast of Billefjord near Cape Ekholm. Coll 1975 and subm by L Troitsky. Comment: outer $40 \%$ removed by acid leaching.

\section{Tln-195. Brögger}

$42,490 \pm 550$

Shells from base of $30 \mathrm{~m}$-terrace on $\mathrm{N}$ coast of Brögger Peninsula. Bedrock overlain by cobble loam, sand, till, red clay, sand with shells and cobble-and-pebble beach deposits. Coll 1975 and subm by L Troitski. Comment: outer $40 \%$ removed by acid leaching.

\section{Tln-252. Brögger}

$33,200 \pm 550$

Shells from same complex as Tln-195. Based on Tln-195, -252, the following conclusions can be drawn: 1) because of contamination of samples, Th-195 reflects min age of complex, 2) occurrence of younger shells in deposits is not excluded, 3) data obtained reflect interval of warming. Coll 1975 by J M Punning and L Troitski. Comment: outer $40 \%$ removed by acid leaching.

Tln-196. Gravsjoem

$1760 \pm 50$

Animal bones near lagoon Gravsjoem, Nordenskjöld Land. Sample from upper layer. Col and subm by V Korjakin, Inst Geog. 
Animal bones from cultural layer near mouth of Homender $R$, Nordenskjöld Land. Sample from uppermost layer. Coll and subm by V Korjakin.

Tln-232. Agardalen

$10,570 \pm 360$

Peat layer from sands from crest of push moraine of Elfenbeinbreen glacier, Sabine Land. Sample from upper part of layer. Coll 1975 and subm by L Troitski.

\section{TIn-233. Agardalen}

Central part of peat layer (see Tln-232).

TIn-234. Agardalen

$$
9460 \pm 110
$$

Lowermost part of peat layer (see Tln-232). Data obtained refer to reverse bedding of complex.

\section{TIn-244. Kalypsobyen}

$16,720 \pm 230$

Shells from surface of $16 \mathrm{~m}$-terrace near Kalypsobyen, Bay of Bellsund. Coll 1976 by J M Punning. Comment: outer $40 \%$ removed by acid leaching.

TIn-250. Kalypsobyen

$17,070 \pm 150$

Repeat analyses of shells from profile of Kalypsobyen (see Tln-244). Comment: outer $40 \%$ removed by acid leaching.

\section{Tln-258. Kalypsobyen}

$10,380 \pm 120$

Shells from surface of $30 \mathrm{~m}$-terrace near Kalypsobyen, Bay of Bellsund. Judging by dates, age of 16m-terrace is too old (see Tln-244, -250), which supposedly resulted from mixing of material used for dating with older material outwashed from base of terrace (see Thn-250). Sample coll 1976 and subm by J M Punning. Comment: outer $40 \%$ removed by acid leaching.

\section{TIn-245. Nathorst}

$1380 \pm 70$

Driftwood from marine deposits in distal part of $\mathrm{E}$ end of Nathorst moraine, Van Keulenfjord. Coll 1976 by J M Punning.

\section{TIn-246. Kap Lyell \\ $440 \pm 70$}

Driftwood from terrace deposits at alt $0.6 \mathrm{~m}$ from sea level, $0.5 \mathrm{~km} \mathrm{~W}$ of cape Kap Lyell (Bellsund). Coll 1976 by J M Punning.

\section{Tln-247. Renarodden}

$$
230 \pm 60
$$

Driftwood from surface of $60 \mathrm{~m}$-terrace near cape Renarodden (Bellsund). Judging by age driftwood is not of primary deposit. Coll 1976 by J M Punning.

\section{TIn-251. Renarodden}

$$
31,910 \pm 600
$$

Shells from intermorainic complex of sea deposits forming bases of 30m-terrace, cape Renarodden, Bellsund. Sample coll 1976 by J M Pun- 
ning. From same complex previous date 30,750 \pm 800: Thn-175 (Punning et al, 1976), which confirms good correlation with last date. Comment: outer $40 \%$ removed by acid leaching.

Tln-249. Blomstrand

$9185 \pm 120$

Shells from surface of $10 \mathrm{~m}$ terrace ( $\mathrm{N}$ coast of Kongsfjord). Coll 1976 and subm by L Troitski.

\section{East Siberia}

Tln-228. Tchaun-1

$35,300 \pm 900$

Biodetrite from borehole on beach of estuary of Tchaun, $2 \mathrm{~km} \mathrm{~S}$ of town Peven on coast of East-Siberian Sea. Ancient lagoon deposits lie between deluvial deposits at depth 3.2 to $4.8 \mathrm{~m}$. Coll 1975 and subm by $\mathrm{F}$ Kovalenko, All-Union Research Inst Marine Geol.

\section{Tln-236. Techaun-2}

$14,180 \pm 350$

Well-decomposed peat from borehole in S part of estuary of Tchaun, East-Siberian Sea. Complex of lake deposits overlain by aleurite and fine sand. Sample from depth 1 to $1.2 \mathrm{~m}$. Coll 1975 and subm by F Kovalenko.

\section{Tln-235. Aion-4}

$7530 \pm 250$

Peat from terrace of erosion coast of Aion I, estuary of Tchaun, EastSiberian Sea. Sample from lower part of peat from drained thermokarst funnel. Coll 1975 and subm by F Kovalenko.

Tln-238. Aion-3

$23,600 \pm 800$

Plant remains from terrace on $\mathrm{E}$ abrasional coast of Aion I, estuary of Tchaun, East-Siberian Sea. Sample from under $13 \mathrm{~m}$ complex of loesslike rocks alternating with horizontal layers of sandy and aleuritic deposits. Coll 1975 and subm by F Kovalenko.

\section{TIn-242. Tchaun}

$13,460 \pm 280$

Peat from subaqueous coastal slope in E Part of tributory Tchaun, East Siberian Sea. Clayey aleurites with peat layers at 4.5 to $5.4 \mathrm{~m}$, overlain by clayey aleurites. Sample coll 1975 and subm by M Rosenblats, AllUnion Research Inst Marine Geol.

\section{Central Asia}

Tln-198. Suphan

$180 \pm 60$

Peat from central part of Suphan bog (Phergana Dist, Uzbek SSR). Sample from depth $0.2 \mathrm{~m}$. Coll 1974 and subm by L. Serebryanny, Inst Geog.

\section{Tln-203. Kerkidon-3}

$5680 \pm 80$

Plant remains from alluvial bog deposits on slope of 2nd terrace of Kuvasay R, $1 \mathrm{~km} \mathrm{NW}$ of village Kerkidon, Aravan Dist, Oshs region, Kirghiz SSR. Sample from depth 0.4 to $0.5 \mathrm{~m}$. Coll 1975 by G Pshenin and L Serebryanny, Inst Geog. 
Tln-204. Kerkidon-4

$7430 \pm 60$

Plant remains from alluvial bog deposits on slope of 2nd terrace of Kuvasay R (see Tln-203).

\section{Tln-205. Kashkalan-1}

$2470 \pm 80$

Peat sapropel from slope of canal $1 \mathrm{~km} \mathrm{~S}$ of village Kashkalan Alabuhinsk Dist, Oshs region, Kirghiz SSR. In profile peat sapropels at depth 1.60 to $1.65 \mathrm{~m}$ and 2.60 to $2.70 \mathrm{~m}$. Sample from upper layer. Coll 1975 and subm by L Serebryanny.

Tln-206. Kashkalan-2

Peat from lowermost horizon from same profile as Tln-205.

TIn-241. Kulandy

Shells from surface of spit of ancient lagoon of Aral Sea $4 \mathrm{~km} \mathrm{~W}$ of village of Kulandy (Aral Dist, Kõzol-Ordinsk region, Kazakh SSR. Sample coll 1976 and subm by I Veinbergs, All-Union Research Inst Marine Geol. Comment: outer 20\% removed by acid leaching.

\section{TIn-243. Kulandy}

$730 \pm 80$

Shells from surface of spit of ancient lagoon of Aral Sea $5 \mathrm{~km} \mathrm{~S}$ of settlement Kulandy. Sample coll 1976 and subm by I Veinbergs. Comment: outer $20 \%$ removed by acid leaching.

\section{ARCHAEOLOGIC SAMPLES}

\section{Estonian SSR}

Tln-207. Pajumóisa

$1468 \pm 80$

Remains of decomposed wood from ancient grave on I Saaremaa. Estimated age: 5th to 6th centuries AD. Sample from depth 0.6 to $0.7 \mathrm{~m}$. Coll 1975 and subm by T Hamla, Inst Hist.

Tln-209. Narva-Jōesuu

$280 \pm 50$

Remains of ancient ship from under old coast dunes near settlement Narva-Jōesuu (estuary of Narva R). Sample coll 1976 by V Iōugas, Inst Hist.

TIn-213. Kuressaare

$960 \pm 60$

Wood from wall of guard tower of castle Kuressaare, I Saaremaa. Sample coll 1975 and subm by K Aluvee, State Blda Comm Council Ministers Estonian SSR, Restoration Office.

\section{TIn-214. Kuressaare}

$690 \pm 60$

Wood from defense wall of castle Kuressaare, I Saaremaa. Sample coll 1975 and subm by K Aluvee.

\section{TIn-218. Kuressaare \\ $630 \pm 50$}

Wood from earlier building stage of Kuressaare castle, I Saaremaa. Coll 1974 and subm by K Aluvee. 
Tln-237. Kaali

Wood from lacustrine deposits in main crater of Kaali, I Saaremaa. Coll 1976 and subm by V Lōugas, Inst Hist.

\section{REFERFNCES}

Devyatova, E and Punning, J M, 1976, Upper-Pleistocene profile Koleshki (Arkhangelsk Dist) and its stratigraphic importance: Acad Sci Estonian SSR pub, v 25, no. 2, p 152-160 (in Russian)

Devyatova, E, Raukas, A, Rajamäe, R, and Hütt, G, 1978, Upper-Pleistocene profile Pasva (Vaga R, Arkhangelsk Dist) and its stratigraphic importance: Comm Quaternary Geol Bull (in press, in Russian).

Hütt, G, Punning, J M, Smirnov, A, and Rajamäe, R, 1978, Reliability of TL dating method in geology: 3rd methodological symposium in geochronol (in press, in Russian).

Punning, J M, Kakum, T, and Rajamäe, R, 1976, Tallinn radiocarbon dates III: Radiocarbon, v 18, p 110-115.

Punning, J M, Rajamäe, R, Ehrenpreis, M, and Sarv L, 1977, Tallinn radiocarbon dates IV: Radiocarbon, v 19, p 111-117. 